Eurasia: Economics \& Business, 1(19), January 2019

DOI https://doi.org/10.18551/econeurasia.2019-01

UDC 332

\title{
ANALYSIS OF THE IMPACT OF SUGARCANE MANAGEMENT SYSTEM ON THE FARMERS INCOME IN MAGETAN DISTRICT, INDONESIA
}

\author{
Arumsari Devinta Nur ${ }^{*}$ \\ Postgraduate program, Faculty of Economic and Business, University of Brawijaya, \\ Indonesia \\ Santoso Dwi Budi, Muljaningsih Sri \\ Faculty of Economic and Business, University of Brawijaya, Indonesia \\ *E-mail: devinta75@gmail.com
}

\begin{abstract}
The under developing management system of the sugarcane farmers in Magetan District, Indonesia. is the contract and non-contract management. The choice taken by the farmers has implications for income. There are differences in income between the two management systems. This study has three objectives. First, to determine the factors that influence the level of farmers income. Second, to find out the factors that influence decisions in the selection of the management system. Third, to find out the different impact in each management system. The research approach method used in this study is quantitative. The management system chosen by sugarcane farmers becomes treatment effect for their income, where the number 1 is for the contracts and 0 for non-contract management. Data collection techniques were carried out by interviewing and distributing questionnaires to 80 respondents. The data analysis tool used is the treatment effect model analysis with the Stata 12.0 program. The results of this study indicate that the main factors that influence farmers' decisions are experience, opportunity cost, wealth. While the factors that cause differences in the amount of income are the scale of production, technology, insight and family labor. The conclusions of this study are: (1) sugarcane farmers still have quite good prospects compared to businesses outside sugar cane plantations; (2) the income of noncontracted farmers is higher than the contract ones; (3) the factors that influence income are the area of the land, fertilizer costs, working costs, organization experience, land area, education and farm management.
\end{abstract}

\section{KEY WORDS}

Management system, sugarcane, farming, farmer income, treatment effect model.

Economic transformation has encouraged the key sectors / leading sectors of the regional economy to increase productivity and drive the added value for regional economic development (Arsyad, 2010). In East Java, there are still many regions with declining productivity based on the agricultural sector. On the other hand, this sector has the largest labour demand. It implies on lack of welfare on many farmers. One of the efforts to improve welfare is by implementing the proper farmingmanagement. Healthy farming management can bring positive economic implications for farmers and companies, as well as increase the income, business continuity and productivity (Manzilati, 2010). Glover and Ghee (1992) said that farming management is divided into two; contract management/partnering with other parties and non-contract/independent. Partnering or contract farmers can provide benefits for themselves and large entrepreneurs, in the matter of factory for processing production. While independent or non-contract farmers are usually the farmers who capable to prepare investment and operational capital all by themselves (Cahyarubin, 2016).

In East Java, there is one regency that still relies on the agricultural sector. Magetan Regency is an area located in the western part of East Java province and is the second smallest district in East Java. If we see Magetan Regency from the distribution of the potential availability of natural and human resources, it has a high opportunity to cover 
ground in the socio-economic field. In terms of managing its agricultural business, Magetan Regency applies two farming management; Contracts and Non-Contracts.

The economic condition in Magetan is still relatively low where the rate of economic growth is far below the average of East Java Province. This also affects the per capita income. The average per capita income in Magetan Regency is still far from the average income in East Java. Likewise with the condition of the workforce. Most people in Magetan work in agriculture with relatively low wages.

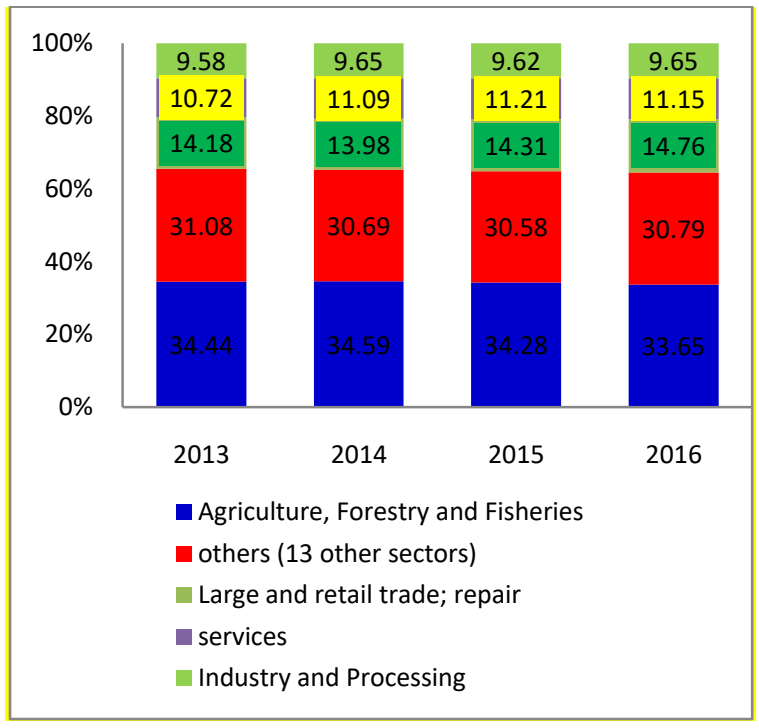

Figure 1 - Economic Structure of Magetan Regency (Source: Central Statistics Agency (BPS) of Magetan Regency, 2017)

From Figure 1 above, it can be seen that the agricultural sector is the biggest contributor to GDP in Magetan. Therefore, there should be more attention and effort from the government to increase regional economic growth focusing on the agricultural sector. Until today, relying only on the agricultural sector is not the solution to improve the welfare of the community in Magetan. In the agricultural sector, there are seven sub-sectors, and Figure 2 explains the contributions of those subsectors.

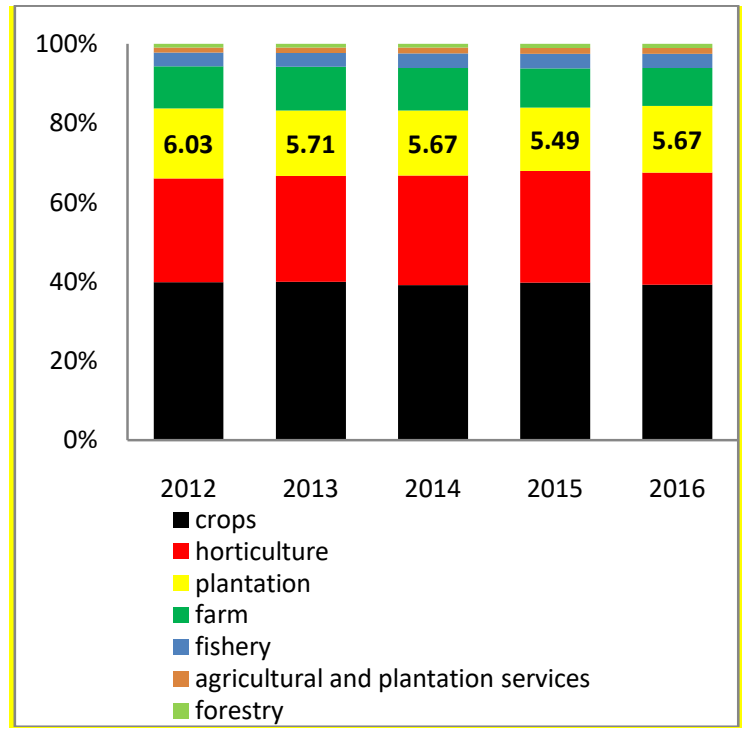

Figure 2 - The contribution of 7 agricultural sub-sectors in Magetan Regency (Source: Central Statistics Agency (BPS) of Magetan Regency, 2017) 
During the period of 2012 to 2016, the contribution of seven sub-sectors in the agriculture shows there are two sub-sectors that have the potential to have a high added value; livestock and plantations subsectors. In Magetan, there are two large industries that influence the movement of economic activity; leather and sugar industries. The sugar industry is related to sugar cane plantations, and the leather industry is related to livestock. In the agricultural sector, the added value is considered as the rising of the commodity value after it undergoes processing, transporting or storing within a production (Soekartawi, 1993).

According to (Khudori, 2002), the sugar industry is closely related to local resources, so that high-value commodities can be developed for the empowerment of the people's economy. Therefore, the existence of the sugar industry can be an economic asset and a very important social asset at the same time.

Economic empowerment in this case is related to sugar cane farmers. This study discussing sugarcane farmers divided into the contract and non-contract management, with the management of sugarcane farmers it should have a bearing on improving the welfare of farmers.

This study aims to identify the factors that influence the decision making of sugarcane farming management and estimate the impact of the decisions on the income levels, considering that in Magetan Regency there are two managements of sugarcane farming; the contract and non-contract system.

\section{LITERATURE REVIEW}

Agricultural Management. In agricultural management, some experts stated that there are two groups of farming management; contract farming and non-contract farming. A farming contract is a production system and agricultural/horticultural products supply under a futures contract between producer/seller and buyer (Goel, 2003). Glover and Ghee (1992) added that farming contracts usually provide some benefits for farmers, including guaranteed markets, access to company services and easy access to the credit application.

According to Hasfah (1999), a partnership is a business strategy carried out by two or more parties within a certain period of time to gain profits together with the principle of mutual need and mutual nurturing, and because it is a business strategy, the success of partnerships is largely determined by the compliance among partners in implementing business ethics.

Based on the above definition, it can be concluded that the partnership is a business affiliation which constitutes a business strategy carried out by two or more parties with the principle of mutual need, mutual reinforcement and mutual benefit accompanied by one development and guidance. This can happen because, basically, each party has weaknesses and strengths, therefore each party will complete each other in the sense that one party will fill in by guiding the weaknesses of the other and vice versa.

On the other hand, non-contract farmers are those who manage their businesses independently, using personal capital, and tend to grow food crops (Agustina, 2011). In the process of decision making to choose farming management, they only rely on individual rationality. A person's decision is based on economic factors, such as how much profit a person will get in each of his activities, how much are the costs and how much total income in total (Levin and Milgrom, 2004). As technology advances and the world develops, choices arise outside rationality. The irrational choice is the kind of choice that someone makes based on other factors, such as tastes, self-esteem, satisfaction, etc. (Levin and Milgrom, 2004).

The choice of sugarcane plantation management taken by farmers has implications for their income. This is because every management has a different variety of costs. The calculation of income is by finding the difference between total revenue (TR) and total cost (TC). Total revenue is influenced by output $(Y)$ and price $(P)$, while the costs consist of production costs, transaction costs and business risks. Dorward (2001) had a hypothesis that the farmer's decision to choose either contract or non-contract is influenced by the level of transaction and risk costs. In addition to that, there is market uncertainty that causes risk 
costs. In Figure 3, there are differences in each management in dealing with conditions of market uncertainty.

The decision to become a contract and non-contractfarmer. However, is also influenced by production costsvariable, organizational transaction costs, and the family expensess. The farmers' desire to get better output in terms of quality and quantity encourages them to add production costsvariable. However, due to a limited budget, farmers have to choose between being independent or non-independent farmers.

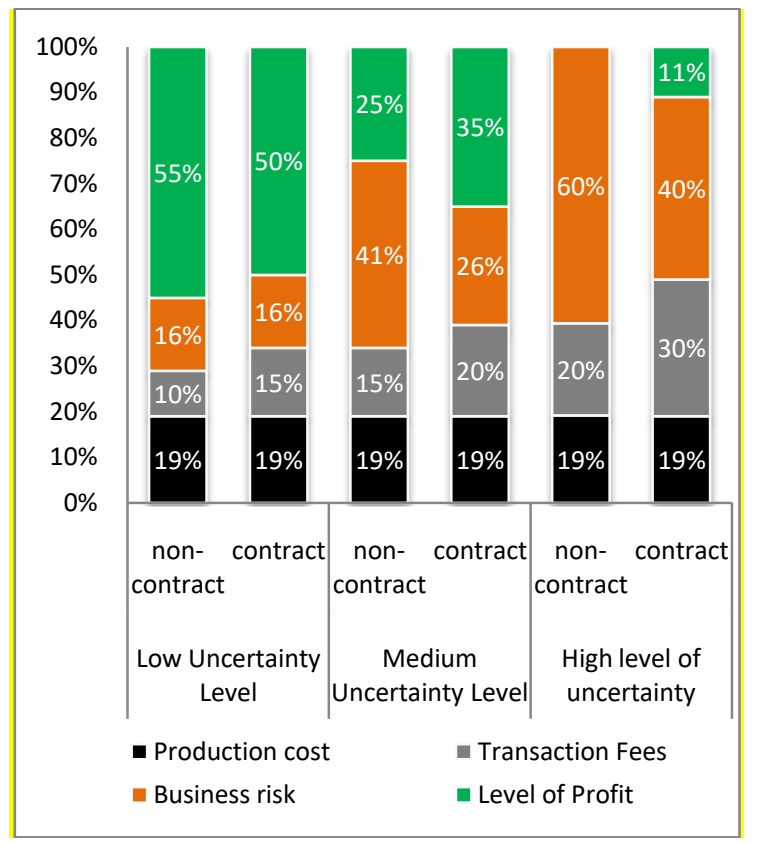

Figure 3 - Two options for sugar cane plantations management

(Source: Modifications from Doward, 2001)

Organizational transaction costs formed from the negotiations or contracts made by farmers. Both contact and non-contract farmers have partnerships. The classic assumption says that transaction costs are zero. While in reality, transaction costs are never zero. The number of transaction costs determines the decision in choosing farming management.

\section{METHODS OF RESEARCH}

Based on the objectives of this study, the researcher uses the quantitative approach. This study, the analysis of sugarcane management impact on the farmers' income in Magetan Regency aims to identify the factors that influence decisions in the farming management and estimate the impact on income levels, considering that there are two management of sugarcane farming in Magetan; contract and non-contract systems.

The data used are primary data with a sample of 80 people. The sampling technique used is proportional random sampling cluster and consist of 40 contract farmers and 40 noncontract farmers respectively. The time of the study started in December 2017 until February 2018.

Treatment Effect Model. Based on the research objectives and research hypothesis, the research tool used is Treatment Effect Models. This method looks at the effect of the average binary variables toward the treated variables (variable outcome) (Heckman and Robb, 1986). In this case, there are variables which are assumed will receive some treatment and some will not receive any treatment. This method can estimate samples by comparing the average values for treated and untreated units. There are two functional equations in this study that can be written as follows:

(i) The Equation of Decision in Choosing Management, which is influenced by age, family expensess, land area, side jobs and education variables. 
(ii) The Equation of Management Impacts on Sugarcane Farmers' Income, which is influenced by the decision variable to choose contract management, side jobs, education, cultivation costs, fertilizer costs, and organization period.

\section{RESULTS AND DISCUSSION}

This study uses a descriptive quantitative method and Treatment Effect Model, aiming at finding out the effect of the average binary variables $(0 / 1)$ toward the variables that receive treatment (outcome variable) (Heckman and Robb, 1986). In the treatment effect model, it is assumed that there are two results; the variable which receives treatment as $\mathrm{y} 1$ and the other variable which is not treated as y0 (Soderbom, 2009). Based on the results of the treatment effect model, the following results are obtained:

\begin{tabular}{|l|c|c|c|c|}
\hline \multicolumn{1}{|c|}{ Variable } & Coefficient & Std. Err & $\mathbf{z}$ & $P>|\mathbf{z}|$ \\
\hline [1] contract Farmer's Decision \\
\hline Age & .0599895 & .0249513 & 2.40 & 0.016 \\
\hline Family Expensess & -.3081042 & .1514461 & -2.03 & 0.042 \\
\hline Land Area & .5271734 & .1521806 & -3.46 & 0.001 \\
\hline Side Jobs & 1.57033 & .5163475 & 3.04 & 0.002 \\
\hline Education & .1092401 & .0797161 & 1.37 & $0.171^{\star}$ \\
\hline \multicolumn{5}{|l|}{} \\
\hline [2] Farmer's Income & 7.764502 & 2.200451 & 17.92 & 0.000 \\
\hline Cons & .6981586 & 2.883047 & -2.03 & 0.015 \\
\hline Contract Management & 8.266057 & .4612766 & -3.46 & 0.000 \\
\hline Land Area & -3333284 & .1546477 & 3.04 & 0.031 \\
\hline Work Cost & .8112378 & .2809122 & 1.37 & 0.005 \\
\hline Fertilizer Costs & .1796438 & .0842568 & 1.30 & 0.033 \\
\hline Education & .0905621 & .0333977 & -2.33 & 0.007 \\
\hline Organization Period
\end{tabular}

Table 1 - Estimation of Treatment Effect Model parameters

Based on Table 1, the Chi-square test of the overall tolerance effect has a chi2 probability of 0.00 (significant at the chosen alpha error rate of $5 \%$ ). Thus, this equation is considered valid to explain the difference in farmer's income which is influenced by the decisions of choosing sugarcane farming management.

The first equation regarding the decision to choose sugarcane agriculture management (Y1) has a significance level of less than $5 \%$. Both the variables of age, family expensess, land area, and side jobs affect the decisions. Partially, as the farmers getting older and their ownership of side jobs increased, the opportunity to choose agricultural contract management will be higher. Conversely, the higher the family's expenses and the area of land owned by farmers, the tendency of farmers to choose to a non-contract management will be higher. As for the education variable, it does not affect farmers in the decisions of choosing sugarcane farming management.

In the second equation regarding the management impact on the farmers' income, Y2 shows that the difference in income of sugarcane farming is influenced by the contract management of sugarcane farming, land area, cultivation costs, fertilizer costs, organization period, and education. Farmers who choose the contract management have a lower income level than the farmers who choose the non-contract management.

The estimation results show that there are four variables that positively influence the income of sugarcane farmers in Magetan; (i) education, (ii) land area, (iii) organization period, and (iv) fertilizer costs.

There are two variables that negatively affect farmers' income; (i) contract management of sugarcane farming, and (ii) working costs. 
Eurasia: Economics \& Business, 1(19), January 2019

DOI https://doi.org/10.18551/econeurasia.2019-01

\section{DISCUSSION OF RESULTS}

The farmers' ability to decide which agricultural management to choose for their farming will affect their success. Success, in this case, is in the term of welfare, measurable by the level of income they earn.

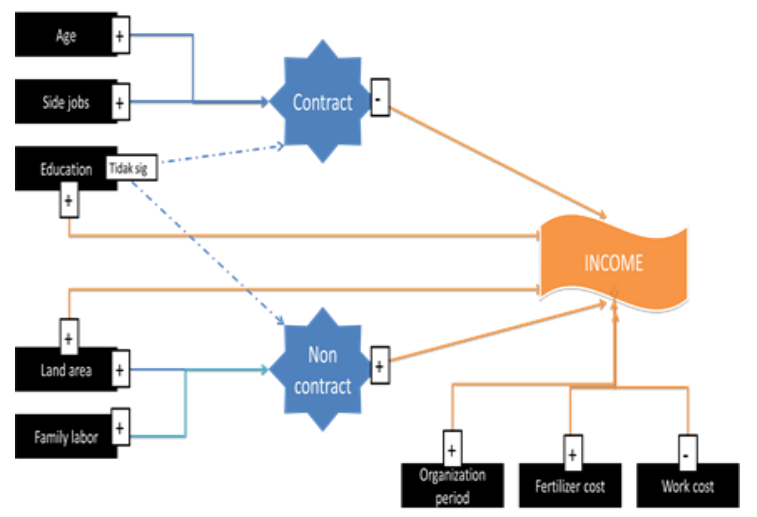

Figure 4 - The Scheme of Farmer Management Impact on income

Based on Figure 4, there are two main discussions to answer the research objectives; identifying the factors that influence decisions in choosing the management of sugarcane cultivation and estimating the impact of the decision on the income levels, considering that there are two management of sugarcane farming in Magetan; contract and non-contract systems. The ability of the farmer to decide which management to choose will affect his success in farming.

Based on the estimation results, the management of sugarcane farming shows a connection to the sugarcane farmers' income. This reflects that the decision of choosing contract management of sugar cane farming actually causes a decrease in farmers' income. Farmers who choose to manage sugarcane farming in contract management is determined by the increasing age and ownership of the side job, while the education level does not have a significant influence on the decision to choose contract management.

Family expenses and area of the land, both have a positive and insignificant effect on the farmers' decision to choose agricultural contract, meaning that it is statistically true and trustworthy that the high family expenses and the wide area of land that will be used by farmers affect the results of business in farming management, while the negative effect means that an increase in family expenses and the area of land will lead to a tendency of farmers to follow non-contract farming management.

Education has a positive effect on the income received by farmers. It is understandable that with high education, farmers are more capable to use sophisticated technology in managing their business, such as tractors and fertilizer sprayers.

In the land area variable, a wide land area will have an impact on the scale of production. The high scale of production is obtained from the extent of land owned by farmers. With the high production scale, it is preconcerted that the expected profits will be high as well, and it affects the income that farmers will earn. The variable of organization period reveals that the longer a farmer joins the organization, the greater their chances of obtaining high-profit expectations from the knowledge he has gained from the organization, so the income they earn will be high as well.

Business expenses for high fertilizer costs will affect the scale of production that occurs, the scale of production itself is the measurement in producing goods or how many goods will be produced. That means the more costs incurred for purchasing fertilizers, the more goods are produced. Therefore, farmers will consider the expected profits and the income received will be high as well. The working cost variable. The results show that in Magetan Regency, most farmers experience financial problems. The more expense on the 
working cost, the more it will affect their income. With the assumption that the working cost which is imposed on farmers has a negative influence on farmers' income.

\section{CONCLUSION}

Management of sugar cane in Magetan Regency has a good prospect to be expanded and developed because farmers' income in this sector is higher compared to other businesses outside the sugar cane plantation. This depends on the influential factors; land area, education, fertilizer costs, and organization period.

The factors that influence farmers' decision to choose farming management include age, family expenses, land area, education, and side jobs. Non-contracted farmers income is higher than contract farmers which may be caused by two things; (i) the supervision costs set by the factory tend to be high, and (ii) the price and quality of the sugarcane determined by the factory may be lower than other factories.

\section{REFERENCES}

1. Agustina, S. (2011). Ilmu Usaha Tani. Malang: UB Press.

2. Arsyad, L. (2010). Ekonomi Pembangunan. Yogyakarta: UPP STIM YKPN.

3. Badan Pusat Statistik. (2010). Statistik Daerah Kabupaten Magetan 2010. Magetan: BPS.

4. Badan Pusat Statistik. (2017). Statistik Daerah Kabupaten Magetan 2017. Magetan: BPS.

5. Badan Pusat Statistik. (2017). Kabupaten Magetan Dalam Angka. Magetan: BPS.

6. Badan Pusat Statistik. (2018). Kabupaten Magetan Dalam Angka 2018. Magetan: BPS.

7. Badan Pusat Statistik. (2017). Statistik Tebu Indonesia. Jakarta: BPS.

8. Cahyarubin, A. (2016). Analisis Pendapatan Usahatani Tebu Petani Mitra dan Non Mitra PG Rejoagung Baru, Kabupaten Madiun (Unpublished Thesis). Institut Pertanian Bogor, Bogor.

9. Dorward, A. (2001). The Effects of Transaction Costs, Power and Risk on Contractual Arrangements: A Conceptual Framework for Quantitative Analysis. Journal of Agricultural Economics,

10. Glover, D,. and Ghee, L. T. (1992). Contract Farming in Shoutheast Asia; Three Country Studies. Malaysia: University of Malaya Kuala Lumpur

11. Goel, S. A. K. (2003). Contract Farming Ventures in India: A Few Successful Cases. SPICE. The Director General, National Institute of Agricultural Extension Management (MANAGE). India:

12. Hasfah, J. M. (1999). Kemitraan Usaha. Jakarta: Pustaka Sinar Harapan.

13. Heckman, J. J., and Robb, R. (1986). Alternative Methods for Solving the Problem of Selection Bias in Evaluating the Impact of Treatments on Outcomes. New York

14. Khudori. (2002). Masa Depan Agroindustri Gula. Jakarta: Sinar Harapan.

15. Manzilati, A. (2010). Implikasi Kontrak Usaha Tani Dengan Perusahaan Terhadap Keberlanjutan Usaha Tani. Wacana, 13,

16. Levin, J., and Milgrom. P. (2004). Introduction to Choice Theory.

17. Weng, M. S. (2009). Binary Choice Models. Sweden: University Of Gothenburg.

18. Soekartawi. (1993). Prinsip Dasar: Agribisnis Teori dan Aplikasinya. Jakarta: PT. Raja Grafindo Persada.

19. Soekartawi. (2002). Analisis Usaha Tani. Jakarta: UI Press. 